Original Paper http://ajol.info/index.php/ijbcs http://indexmedicus.afro.who.int

\title{
Sustainable management of coastal saline soils in the Saloum river Basin, Senegal
}

\author{
Aïdara C. A. Lamine FALL \\ Department of Geography, University Assane Seck of Ziguinchor, BP 523 Ziguinchor, Senegal. \\ E-mail: cherif.fall@univ-zig.sn; Tel.: +221 773934630
}

\begin{abstract}
Salinization of soils is one of the major environmental problems facing the world. Frequent tidal intrusions and continuous decrease of annual rainfall support the salinization of soils in the coastal area of the Saloum river Basin, West Central of Senegal, West Africa. This study aimed at appreciating the spatial variability of soil salinity along a levee to backswamp toposequence in the Saloum River basin; in order to assess the constraints and potentialities of these saline soils and propose sustainable soil management strategies. One transect $(2.2 \mathrm{~km})$ oriented East-West, including 9 soil profiles located on three topographic units: floodplain, low terrace, and middle terrace was selected. Soil chemical properties (electrical conductivity, $\mathrm{pH}$, water soluble cations and anions) were analysed to estimate the salinity level at each soil horizon $(\mathrm{n}=45)$. Soil $\mathrm{pH}(3.5-8.5)$, electrical conductivity $\left(0.01-55 \mathrm{dS} \mathrm{m}{ }^{-1}\right)$ and water-soluble cations $\left(\mathrm{Na}^{+}, \mathrm{K}^{+}\right.$, $\left.\mathrm{Ca}^{2+}, \mathrm{Mg}^{2+}\right)$ and anions $\left(\mathrm{Cl}^{-}, \mathrm{SO}_{4}{ }^{2-}\right)$ decrease with altitude. The study demonstrates the close correlation between landscape position and soil salinity illustrated by a two-dimensional salt distribution pattern: horizontal and vertical. The horizontal pattern is appreciable at landscape scale and supports different salinity level between the three topographic positions. The vertical pattern occurs within soil profiles and is closely linked to soil texture and groundwater dynamic. The topographic position exerts thus the major influence on soil salinity along the toposequence. Mulching appears ultimately as the most efficient method in reclaiming these coastal saline soils.
\end{abstract}

(C) 2017 International Formulae Group. All rights reserved.

Keywords: soil salinity, soil management, Saloum river basin, Senegal, West Africa

\section{INTRODUCTION}

Soil salinization is one of the main problems in arid and semiarid regions (UNEP, 1991). It reduces soil quality, limits the growing of crops, constrains agricultural productivity and, in severe cases, leads to the abandonment of agricultural soils (Amezketa, 2006; Acosta et al. 2011). Salinity problems are caused from the accumulation of soluble salts in the root zone. These excess salts reduce plant growth and vigor by altering water uptake and causing ion-specific toxicities or imbalances. High salt concentrations can induce osmotic stress in plants and lead to the toxic accumulation of ions, such as $\mathrm{Cl}^{-}$and $\mathrm{Na}^{+}$(Hasegawa et al., 2000; Maathuis, 2006), particularly in the surface soil horizons (Ohrtman et al., 2012). Establishing good drainage is generally the cure for these problems, but salinity problems are often more complex (Bauder et al., 2014). Worldwide, more than 800 million hectares of land are estimated to be salt-affected (FAO, 2008), and approximately $10 \%$ of the Earth's 
total land surface may be salt-affected (Schofield and Kirkby, 2003). These soils cover a range of soils defined as saline, saline-sodic and sodic (Ghassemi et al., 1995). Even though the general assumption is that salt-affected soils occur primarily in arid and semiarid climates, these soils are actually found in every climatic zone in every continent except Antarctica (Rengasamy, 2006, 2010). In Australia, concern has risen over salinization and the accompanying decline of riparian vegetation in many of their floodplain systems (Holland et al., 2006; Costelloe et al., 2008), with an insufficient understanding of groundwater-surface water interactions cited as the primary factor currently hampering management (Lamontagne et al., 2005). Increasing salinity has also been implicated in the loss of large areas of Acacia xanthophloea (fever tree) woodlands in south and east Africa (Mills, 2006; Humphries et al. 2011). Salt accumulation in shallow groundwater systems has been observed in a range of wetland environments, including the swamps of the Okavango Delta, Botswana (McCarthy et al., 1993); the Pantanal, Brazil (Barbiero et al., 2002); prairie wetlands in North America (Arndt and Richardson, 1993); and Australian floodplains (Salama et al., 1993; Jolly et al., 1993). Many of the parameters relevant to salinization processes are related to elevation and landscape position. These include rainfall, vegetation, soils, geology, geomorphology and farming practices (tree clearing and ploughing). These have all affected surface shape and runoff patterns. In addition, groundwater levels often correlate well with topography (Salama et al., 1993), causing salinity to occur in low areas, convergent areas and at breaks of slope (Dowling et al., 2003). Although soil salinity is recognized as a major limitation to cropping and the focus of many plant breeding efforts to produce saltresistant crops, generally, it is neglected as a factor in plant ecology, except in the ecology of deserts (salt pans and playas) and wetlands (salt marshes, mangroves) where its importance is obvious given the prevalence of halophytes (Bui, 2013). Evaluating the spatial variability of basic soil properties in saline soils, and mapping the spatial distributions of these soil properties, can help farmers and agricultural managers make effective sitespecific management decisions (Zheng et al., 2009).

The coastal region of West Central Senegal is a low - lying land raising only a few meters above sea level. This situation allows seawater to flow as far as $100 \mathrm{~km}$ inland through the main channels and into the estuaries of tidal rivers, particularly the Saloum River. The intrusion of seawater results, in this particular zone, in the formation of saline soils, which render the land unfit for agricultural production. The area affected by this kind of salinization is estimated to be as large as one million hectares (Fall, 2010), and is continuously expanding. Previously confined on lowlands (floodplain, low terrace), saline soils are now identified on all landscape positions, including arable uplands (middle and high terraces) (fall, 2010). Soils in this coastal area have been subject to some research in the past. Sène and Matty (2014), Faye et al. (2014) and Thiam et al. (2015) analysed their agronomic and forestry potentialities for soilmanagement purposes. Fall (2010) and Fall et al. (2014) studied the genesis and mineralogy of saline acid sulphate soils (ASS) in the Saloum river Basin for sustainable land use and management. But these studies have seldom been oriented on sustainable soil management strategies for efficient land use. In the present study the spatial variation of soil salinity on different landscape positions along a levee to backswamp toposequence in the coastal area of the Saloum River Basin, west central of Senegal was investigated in order to assess the constraints and potentialities of these soils and propose sustainable soil management strategies.

\section{MATERIALS AND METHODS}

Field measurements and site factors The Saloum River Basin (13 $35^{\prime}$ $14^{\circ} 30^{\prime} \mathrm{N}$ and $\left.16^{\circ} 00^{\prime}-16^{\circ} 50^{\circ} \mathrm{W}\right)$, with about 250.000 ha, belongs to the transitional region between Sahelian and Sudanian zones of West 
Central Senegal. The distance of the investigated toposequence is $2.2 \mathrm{~km}$. The sampling transect is oriented East-West and runs across the estuary (Figure 1). It has a general slope of $0.5 \%$.

Topography was determined using a theodolite (Fall, 2010). According to the WRB (FAO, 2006), soils were described in January - February 2007 and April - May 2008, during the dry season. Spatial variability of soil properties was explored through 9 soil profiles along the toposequence; three on the floodplain, as well as on the low terrace and the middle terrace. They are a good cross-section of regional soil genesis and development pattern. Electrical conductivity (EC) and $\mathrm{pH}$ values were first estimated in the field with field $\mathrm{EC}$ and $\mathrm{pH}$ meters (WTW, 8120 - Weilheim, Germany) before a repetition in laboratory under standard conditions. Groundwater level (GWL) was daily estimated with a measuring tape, during the dry season (January-February, 2007 and March-April, 2008) through 42 piezometers (Fall, 2010).

\section{Laboratory work}

Samples were dried at room temperature. Particle-size distribution was performed after organic matter removal with $\mathrm{H}_{2} \mathrm{O}_{2}$ and excessive salts removal by repeated addition of deionised water, centrifugation and decantation until the EC dropped to $\leq 40$ $\mu \mathrm{S} / \mathrm{cm}$ (Schlichting et al., 1995). After subsequent addition of $\mathrm{NH}_{3}$ for water dispersion, overnight shaking and ultrasonic treatment, the sand fractions were obtained by wet-sieving, while the silt and clay fractions were separated by pipette analysis after Köhn (Schlichting et al., 1995).

The soil $\mathrm{pH}$ was measured in a $0.01 \mathrm{M}$ $\mathrm{CaCl}_{2}$ solution and water (1:2.5 by weight, 10 $\mathrm{g}$ air dry soil mixed with $25 \mathrm{ml}$ deionised water) and determined with a $\mathrm{pH}$-electrode. The electrical conductivity (ECe) was measured on solutions extracted by centrifugation of 1:5 soil-water (20 g air dry soil in $100 \mathrm{ml}$ deionised water) mixtures (Schlichting et al., 1995).
The water-soluble cations $\left(\mathrm{Na}^{+}, \mathrm{Ca}^{2+}\right.$, $\mathrm{Mg}^{2+}$, and $\left.\mathrm{K}^{+}\right)$and anions $\left(\mathrm{Cl}^{-}, \mathrm{SO}_{4}{ }^{2-}\right)$ were measured in 1:20 soil-water extracts and determined using flame photometer (ELEX 6361, Natheler + Hinz GmbH, Hamburg, Germany) for $\mathrm{Na}^{+}, \mathrm{Ca}^{2+}$, and $\mathrm{K}^{+}$; atomic absorption spectroscopy (AAS; Perkin Elmer model 3100, Perkin-Elmer GmbH, Überlingen, Germany) for $\mathrm{Mg}^{2+}$; and ion chromatography (Dionex 2000i, Dionex, Sunnyvale, CA) for $\mathrm{Cl}^{-}$and $\mathrm{SO}_{4}{ }^{2-}$. Cations $\left(\mathrm{Na}^{+}, \mathrm{K}^{+}, \mathrm{Ca}^{2+}\right.$ and $\left.\mathrm{Mg}^{2+}\right)$ and anions $\left(\mathrm{Cl}^{-}\right.$and $\left.\mathrm{SO}_{4}{ }^{2-}\right)$ were thereafter individually presented to assess their abundance at two different depths: $0-30 \mathrm{~cm}$ and $30-60 \mathrm{~cm}$. This depth corresponds with the root zone of the investigated profiles. The method used assumes that the available cations or anions in the sample sum to $100 \%$ and the individual cation is a fraction of the total. Other anions, mainly $\mathrm{NO}^{3-}, \mathrm{CO}_{3}{ }^{2-}, \mathrm{PO}_{4}{ }^{3-}$, were excluded from this estimation; they were either not detectable or show trace amounts in all samples. All soil analyses were performed in duplicate on the fine earth fraction $(<2 \mathrm{~mm})$. Results are expressed on the basis of the ovendry $\left(105{ }^{\circ} \mathrm{C}\right)$ soil weight. Graphics were performed using the Excel software, 2013.

A Scanning Electron Microscope (SEM) (LEO 420; LEO Electron Microscopy Ltd, Cambridge, UK) equipped with a field emission cathode and coupled to an Energy Dispersive X-ray (EDX; INCA 400 system, Oxford Instruments, Abingdon, UK) was performed in the fine earth fraction to confirm the mineral composition in some selected samples.

\section{RESULTS}

Variation of soil salinity along the toposequence

Soil salinity was investigated through the ECe and the water-soluble cations $\left(\mathrm{Na}^{+}\right.$, $\left.\mathrm{K}^{+}, \mathrm{Ca}^{2+}, \mathrm{Mg}^{2+}\right)$ and anions $\left(\mathrm{Cl}^{-}, \mathrm{SO}_{4}{ }^{2-}\right)$. Values of ECe, $\mathrm{Na}^{+}$and $\mathrm{Cl}^{-}$(respectively the dominant cation and anion) increase seaward; with a maximum obtained in the floodplain profiles $\left(\mathrm{ECe} \leq 55.5 \mathrm{dS} \mathrm{m}^{-1}, \mathrm{Na}^{+} \leq 33.2 \mathrm{cmol}\right.$ $\left.\mathrm{c}+\mathrm{kg}^{-1}, \mathrm{Cl}^{-} \leq 37.7 \mathrm{cmol} \mathrm{c}+\mathrm{kg}^{-1}\right)$. With $\mathrm{ECe} \leq$ $10 \mathrm{dS} \mathrm{m}^{-1}, \mathrm{Na}^{+} \leq 2.8 \mathrm{cmolc}+\mathrm{kg}^{-1}$, and $\mathrm{Cl}^{-} \leq 5.5$ 
cmolc $+\mathrm{kg}^{-1}$, appear low terrace soils less saline than floodplain soils, but more saline than the middle terrace soils $(\mathrm{ECe} \leq 2.5 \mathrm{dS}$ $\mathrm{m}^{-1}, \mathrm{Na}+\leq 0.007 \mathrm{cmol} \mathrm{c}+\mathrm{kg}^{-1}, \mathrm{Cl}-\leq 0.09$ cmol c $\left.+\mathrm{kg}^{-1}\right)$ (Table 1).

\section{Floodplain soils}

Water soluble cations occur in the floodplain soils in the following order of abundance: $\mathrm{Na}^{+}>\mathrm{Mg}^{2+}>\mathrm{Ca}^{2+}>\mathrm{K}+$, and anions in this order: $\mathrm{Cl}^{-}>\mathrm{SO}_{4}{ }^{2-}$ (Figure 2). Sodium $\left(\mathrm{Na}^{+}\right)$and Chloride (Cl-) dominate hence in the cation and anion pools, respectively; this reflects their marine origin on this lowest landscape position. They show similar distribution trend as ECe, with the highest values in the top- and subsoil, traducing the influence of the shallow saline groundwater table and the surface salt crusts. Magnesium $\left(\mathrm{Mg}^{2+}\right)$ is the second most abundant water soluble cation present in the floodplain soils; it remains almost stable with depth. Calcium $\left(\mathrm{Ca}^{2+}\right)$ and potassium $\left(\mathrm{K}^{+}\right)$ decrease appreciably with depth (Figure 2). Chloride remains also nearly constant within floodplain profiles, except for the topmost horizons (Az, Azm, and Ahz for P1, P2, and $\mathrm{P} 3$, respectively) where it decreases slightly at the expense of sulfate $\left(\mathrm{SO}_{4}{ }^{2-}\right)$ (Figure 2).

\section{Low terrace soils}

Water soluble cations occur in the low terrace soils in the following order of abundance: $\mathrm{Na}^{+}>\mathrm{Mg}^{2+}>$ or $<\mathrm{Ca}^{2+}>\mathrm{K}^{+}$, and anions in this order: $\mathrm{Cl}^{-}>\mathrm{SO}_{4}{ }^{2-}$ (Figure 2). Values of $\mathrm{Na}^{+}$and $\mathrm{Cl}^{-}$remain the most abundant in soils on this intermediate landscape position. They decrease with altitude, being lower throughout P6 compared to P4 and P5; but increase altogether with depth, traducing the groundwater influence. The previous order of cation availability noted in the floodplain soils is somewhat altered by the predominance of $\mathrm{Ca}^{2+}$ relative to $\mathrm{Mg}^{2+}$ throughout profiles, mainly P6 (Figure 2). Except for the subsoil of P4, important values of $\mathrm{Ca}^{2+}$ and $\mathrm{Mg}^{2+}$ were obtained. This important abundance of $\mathrm{Ca}^{2+}$ and $\mathrm{Mg}^{2+}$ reflects the acid conditions of low terrace soils. Under such conditions, the base cations are replaced by acid cations (mainly $\mathrm{H}^{+}$in the studied soils) and normally leached out of the system. Their presence supports, therefore, restricted leaching process due to the presence of clayey subsoil material in these profiles. Anions show a similar order of abundance as in the floodplain profiles: $\mathrm{Cl}^{-}>\mathrm{SO}_{4}{ }^{2-}$, with $\mathrm{SO}_{4}{ }^{2-}$ increase and $\mathrm{Cl}$ decrease in the topsoil of soil profiles (Figure 2).

\section{Middle terrace soils}

Water soluble cations and anions show their lowest values in the middle terrace profiles (Figure 2). This supports the absence of marine influence coupled with a nearly complete leaching of salts during the rainy season on this highest landscape position. The abundance order of cations is represented as follows: $\mathrm{Na}^{+} \geq \mathrm{K}^{+} \geq \mathrm{Ca}^{2+} \geq \mathrm{Mg}^{2+}$. So apart from an important increase of $\mathrm{Na}^{+}$in the subsoil of P8 and P9, cations seem in better equilibrium in the middle terrace soils compared with the other topographic positions (Figure).

Salinization of soils in this coastal area is caused by the intrusion of hypersaline water from the Atlantic Ocean through tidal inundations and capillary rise from a shallow saline groundwater. The intensity of tidal inundations decreases uplands, while the groundwater depth increases in the same direction. The floodplain soils appear therefore more saline relative to the low terrace and the middle terrace soils.

Apart from having a high salt content, salt-affected soils show also considerable diversity in their biological, physical, chemical, mineralogical and micromorphological characteristics. Salts precipitate at the surface or accumulate in the soil profile as diverse minerals (Wongpokhom et al., 2009; Bui, 2013). Halite $(\mathrm{NaCl})$ remains the most abundant salt mineral in the studied soils. It shows a seaward increase and wellstructured crystals in some soil aggregates from the floodplain (Plate 1a) and low terrace (Plate 1b) profiles. Preference was given to the topsoil of soil profiles marked by the presence of salt crusts resulting from the intense evaporation of the saline groundwater. 
Table 1: Selected soil properties of the study sites.

\begin{tabular}{|c|c|c|c|c|c|c|c|c|c|c|c|c|c|c|}
\hline \multirow{3}{*}{$\begin{array}{l}\text { Depth } \\
\text { (cm) }\end{array}$} & \multirow{3}{*}{ Horizon } & \multirow{3}{*}{ Colour } & \multirow{2}{*}{\multicolumn{3}{|c|}{$\begin{array}{c}\text { Texture } \\
(\%)\end{array}$}} & \multirow{2}{*}{\multicolumn{2}{|c|}{ pH }} & \multirow{3}{*}{$\begin{array}{c}\text { EC } \\
\mathbf{d S}^{-1} \mathbf{m}^{-1}\end{array}$} & \multicolumn{6}{|c|}{ Water soluble Ions $\left(\mathrm{cmol}_{\mathrm{c}^{+}} \mathrm{kg}^{-1}\right)$} \\
\hline & & & & & & & & & \multicolumn{4}{|c|}{ Cations } & \multicolumn{2}{|c|}{ Anions } \\
\hline & & & Sand & Silt & Clay & $\mathrm{CaCl}_{2}$ & $\mathrm{H}_{2} \mathrm{O}$ & & $\overline{\mathrm{Na}^{+}}$ & $\overline{\mathbf{K}^{+}}$ & $\mathrm{Ca}^{2+}$ & $\mathrm{Mg}^{2+}$ & $\mathrm{Cl}^{-}$ & $\mathrm{SO}_{4}^{2-}$ \\
\hline
\end{tabular}

Floodplain (P1), Gleyic Hyposalic Solonchak (Sulphatic), 1404' 27.4’’ N / 016. 11' 17.4’’ W

\begin{tabular}{|c|c|c|c|c|c|c|c|c|c|c|c|c|c|c|}
\hline $0-1$ & $\mathrm{Az}$ & $7.5 Y 4 / 1$ & 24.5 & 56.7 & 18.8 & 8.2 & 8.4 & 26.5 & 10 & 0.2 & 1 & 2.4 & 14.5 & 1.4 \\
\hline $1-4$ & $\mathrm{Bjz}$ & 7.5YR5/6 & 25.6 & 37.4 & 37 & 7.8 & 7.9 & 11 & 4.7 & 0.1 & 0.3 & 0.9 & 5.6 & 0.5 \\
\hline $4-23$ & Bjv & $7,5 \mathrm{YR} 4 / 2$ & 17.9 & 34.8 & 47.2 & 6.1 & 6.1 & 12 & 5.2 & 0.1 & 0.2 & 0.9 & 5.7 & 0.3 \\
\hline $23-60$ & $\mathrm{Bv}$ & 10YR3/3 & 29.4 & 31.4 & 39.2 & 4.5 & 4.5 & 15.5 & 7 & 0.1 & 0.2 & 1.2 & 8.2 & 0.4 \\
\hline
\end{tabular}

Floodplain (P2), Gleyic Hypersalic Solonchak (Sulphatic), 140 $04^{\prime} 23.8^{\prime \prime} \mathrm{N} / 016.11^{\prime} 16.6^{\prime \prime} \mathrm{W}$

\begin{tabular}{|c|c|c|c|c|c|c|c|c|c|c|c|c|c|c|}
\hline $0-1$ & Azm & $\begin{array}{c}5 Y 3 / 1 \\
5 Y R 5 / 8\end{array}$ & 22.8 & 45.7 & 31.5 & 7.8 & 7.9 & 55.5 & 33.2 & 0.3 & 2 & 5.1 & 37.7 & 2.6 \\
\hline $1-8$ & $\mathrm{Az}$ & $2.5 \mathrm{Y} 4 / 1$ & 27.6 & 32.9 & 39.4 & 7.8 & 8.0 & 9 & 3.8 & 0.2 & 0.3 & 0.9 & 4.3 & 0.4 \\
\hline $8-30$ & Cjr & $\begin{array}{c}2.5 \mathrm{YR} 3 / 1 \\
1 \mathrm{NVD} 7 / 6\end{array}$ & 21.3 & 30.7 & 47.7 & 7.3 & 7.5 & 8.5 & 4.2 & 0.1 & 0.2 & 0.7 & 4.5 & 0.3 \\
\hline $30-60$ & $\mathrm{Cr}$ & 7.5YR2/2 & 42.3 & 30.5 & 27.2 & 5.0 & 5.0 & 14 & 6.5 & 0.1 & 0.2 & 1.9 & 7.8 & 0.4 \\
\hline
\end{tabular}


A.C. A. L. FALL / Int. J. Biol. Chem. Sci. 11(4): 1903-1919, 2017

Floodplain (P3), Gleyic Hyposalic Solonchak (Sulphatic), 14 04' 21.4', N / 016. 11' 06.0' 'W

$\begin{array}{ccccccccccccccc}0-5 & \text { Ahz } & 7.5 \text { YR5/4 } & 75.2 & 21.6 & 3.2 & 7.6 & 7.8 & 12.5 & 4.2 & 0.08 & 1.4 & 1.5 & 5.5 & 1.4 \\ 5-11 & \text { Cz } & 10 \text { YR7/2 } & 69.8 & 25.9 & 4.3 & 7.0 & 7.3 & 7 & 2.4 & 0.06 & 0.6 & 0.7 & 2.5 & 0.7 \\ 11-17 & \mathrm{C} & 10 \text { YR6/4 } & 79.5 & 17.8 & 3.1 & 6.2 & 6.5 & 5.5 & 1.4 & 0.05 & 0.6 & 0.4 & 2 & 0.6 \\ 17-26 & \text { B11 } & 7.5 \text { YR5/8 } & 83.6 & 10.7 & 6.1 & 5.4 & 5.5 & 5.5 & 2 & 0.06 & 0.3 & 0.5 & 2.3 & 0.2 \\ 26-34 & \text { Bl2 } & \text { Mottled } & 78.9 & 12.2 & 8.8 & 6.2 & 6.3 & 7 & 3 & 0.07 & 0.4 & 0.7 & 3.8 & 0.2 \\ 34-70 & \text { Bhr } & 7.5 Y R 2 / 1 & 64.3 & 11.0 & 24.7 & 6.2 & 6.2 & 16 & 7.3 & 0.2 & 0.4 & 1.5 & 7 & 0.5\end{array}$

Haplic Gleysol (Thionic), 1404' 19.4', N / 016. 10'59.2'’ $\mathrm{W}$

$\begin{array}{cccccccccccccccc}0-2 & \text { Ah1 } & 7.5 \text { YR3/3 } & 57.2 & 26.4 & 16.3 & 4.0 & 4.1 & 0.5 & 1.7 & 0.02 & 0.6 & 0.6 & 2.3 & 0.2 \\ 2-16 & \text { Ah2 } & 10 \text { YR4/4 } & 57.9 & 18.3 & 23.7 & 4.8 & 5.0 & 2.5 & 0.1 & 0.004 & 0.003 & 0.001 & 0.08 & 0.03 \\ 16-38 & \text { B11 } & 7.5 \text { YR4/3 } & 61.8 & 18.3 & 20 & 4.2 & 4.5 & 4.5 & 0.2 & 0.006 & 0.01 & 0.01 & 0.1 & 0.03 \\ 38-62 & 2 \mathrm{~B} 12 & 10 \mathrm{R} 4 / 3 & 45.8 & 23.3 & 30.9 & 4.2 & 4.3 & 7.5 & 0.3 & 0.006 & 0.02 & 0.02 & 0.3 & 0.03 \\ 62-90 & 2 \mathrm{~B} 13 & 5 \mathrm{Y} 6 / 1 & 46.0 & 21.3 & 32.7 & 4.5 & 4.5 & 9.5 & 0.4 & 0.008 & 0.03 & 0.03 & 0.4 & 0.04 \\ 90-100 & \text { 2Brl } & 2.5 \mathrm{Y} 5 / 2 & 41.8 & 23.6 & 34.6 & 4.9 & 4.7 & 1 & 0.4 & 0.01 & 0.03 & 0.03 & 0.4 & 0.04\end{array}$

Low Terrace (P5), Haplic Gleysol (Thionic), 14 ${ }^{\circ} 04^{\prime} 20.3$ '’ $\mathrm{N} / 16.10^{\prime} 59.5$ '’ $\mathrm{W}$

$\begin{array}{cccccccccccccrrr}0-2 & \text { Ahz1 } & \text { 10YR3/3 } & 70.4 & 19.7 & 9.7 & 4.5 & 4.4 & 1 & 2.8 & 0.1 & 0.9 & 2.2 & 5.5 & 0.2 \\ 2-11 & \text { Ahz2 } & \text { 10YR3/4 } & 62.5 & 18.3 & 19.1 & 3.9 & 3.9 & 0.5 & 1.2 & 0.07 & 1.8 & 1.2 & 3 & 0.5\end{array}$


A.C. A. L. FALL / Int. J. Biol. Chem. Sci. 11(4): 1903-1919, 2017

\begin{tabular}{|c|c|c|c|c|c|c|c|c|c|c|c|c|c|c|}
\hline $11-29$ & Bwz & 10YR4/6 & 46.7 & 22.4 & 31 & 3.8 & 3.9 & 4.5 & 1.1 & 0.06 & 0.3 & 0.9 & 2.4 & 0.04 \\
\hline $29-51$ & Bl1 & $2.5 \mathrm{YR} 4 / 6$ & 50.0 & 21.4 & 28.6 & 3.7 & 3.7 & 3 & 0.8 & 0.04 & 0.2 & 0.6 & 1.6 & 0.03 \\
\hline $51-81$ & $\mathrm{~B} 12$ & $2.5 \mathrm{Y} 6 / 2$ & 48.7 & 21.3 & 30 & 3.8 & 3.9 & 2.5 & 0.7 & 0.03 & 0.2 & 0.3 & 1.1 & 0.03 \\
\hline
\end{tabular}

Low Terrace (P6), Haplic Gleysol (Thionic), 14 04' 21.2’’N / 016. 10' 51.6’'W

$\begin{array}{cccccccccccccccc}0-4 & \text { Ahz } & \text { 10YR2/3 } & 82.1 & 12.8 & 5.1 & 5.9 & 5.9 & 10 & 2.2 & 0.01 & 1.6 & 1.4 & 5.4 & 0.09 \\ 4-32 & \text { Ahlz } & \text { 10YR2/2 } & 67.6 & 21.8 & 10.5 & 4.4 & 4.4 & 6 & 1.2 & 0.008 & 1 & 0.8 & 3 & 0.06 \\ 32-62 & \text { Bl1 } & 10 \text { YR4/6 } & 71.0 & 20.0 & 8.8 & 4.0 & 3.9 & 5 & 0.9 & 0.005 & 0.8 & 0.7 & 2.6 & 0.04 \\ 62-82 & \text { B12 } & 10 \text { YR5/6 } & 68.6 & 17.2 & 14.3 & 3.9 & 3.8 & 4 & 0.7 & 0.004 & 0.8 & 0.7 & 2.1 & 0.03 \\ 82-110 & \text { Brl } & \text { 10YR4/6 } & 61.7 & 12.4 & 26 & 3.8 & 3.7 & 5.5 & 1.9 & 0.006 & 0.8 & 0.8 & 2.8 & 0.03\end{array}$

Middle Terrace (P7), Endogleyic Arenosol, $14^{\circ} 04^{\prime} 15.9^{\prime}$ 'N / 016. 10' 47.5'’ $\mathrm{W}$

\begin{tabular}{|c|c|c|c|c|c|c|c|c|c|c|c|c|c|c|}
\hline $0-26$ & Ap & 10YR3/4 & 85.1 & 9.7 & 5.1 & 4.1 & 4.7 & 0.01 & 0.001 & 0.002 & 0.001 & 0.0004 & 0.002 & 0.001 \\
\hline $26-60$ & $\mathrm{Ah}$ & $10 \mathrm{YR} 3 / 4$ & 79.8 & 1.0 & 6.2 & 4.2 & 4.7 & 0.04 & 0.001 & 0.001 & 0.001 & 0.0004 & 0.002 & 0.001 \\
\hline $60-108$ & $\mathrm{Cw}$ & $7.5 \mathrm{R} 8 / 3$ & 90.4 & 8.6 & 0.8 & 4.6 & 5.3 & 0.02 & 0.0002 & 0.001 & 0.001 & 0.0001 & 0.002 & 0.001 \\
\hline $108-160$ & $\mathrm{Bl}$ & 7.5YR7/4 & 88.4 & 9.7 & 1.8 & 4.9 & 5.4 & 0.03 & 0.0004 & 0.001 & 0.001 & 0.0002 & 0.002 & 0.001 \\
\hline
\end{tabular}


A.C. A. L. FALL / Int. J. Biol. Chem. Sci. 11(4): 1903-1919, 2017

Middle Terrace (P8), Endogleyic Arenosol, N 14 04' 14.0', / W 016. 10' 47.1'”

\begin{tabular}{|c|c|c|c|c|c|c|c|c|c|c|c|c|c|c|}
\hline $0-31$ & Ap & $10 \mathrm{YR} 2 / 2$ & 77.6 & 15.3 & 7.1 & 4.6 & 4.9 & 0.03 & 0.001 & 0.001 & 0.001 & 0.001 & 0.002 & 0.001 \\
\hline $31-62$ & $\mathrm{AhC}$ & $10 \mathrm{YR} 3 / 2$ & 78.8 & 18.3 & 3 & 5.2 & 5.7 & 0.03 & 0.001 & 0.001 & 0.001 & 0.001 & 0.002 & 0.001 \\
\hline $62-107$ & $1 \mathrm{Cw}$ & 7.5YR7/3 & 82.1 & 15.9 & 2 & 5.6 & 6.0 & 0.03 & 0.0004 & 0.001 & 0.001 & 0.001 & 0.002 & 0.001 \\
\hline $107-138$ & 2B1 & 10YR6/3 & 72.9 & 10.7 & 16.4 & 5.8 & 5.8 & 0.20 & 0.007 & 0.002 & 0.002 & 0.002 & 0.004 & 0.002 \\
\hline $138-160$ & $1 \mathrm{Bl}$ & 10YR8/2 & 83.5 & 12.5 & 4.3 & 6.0 & 6.4 & 0.05 & 0.001 & 0.001 & 0.0005 & 0.0002 & 0.002 & 0.002 \\
\hline
\end{tabular}

Middle Terrace (P9), Endogleyic Arenosol, 14 04 ' 14.0' ' $\mathrm{N} / 016.10$ ' 47.2' $\mathrm{W}$

\begin{tabular}{|c|c|c|c|c|c|c|c|c|c|c|c|c|c|c|}
\hline $0-36$ & Ap & $10 \mathrm{YR} 2 / 3$ & 67.5 & 18.2 & 14.3 & 5.8 & 6.0 & 0.15 & 0.001 & 0.001 & 0.001 & 0.001 & 0.003 & 0.001 \\
\hline $36-67$ & $\mathrm{Ah}$ & 10YR3/3 & 64.6 & 20.3 & 15.1 & 6.2 & 6.5 & 0.10 & 0.002 & 0.002 & 0.002 & 0.002 & 0.002 & 0.001 \\
\hline $67-88$ & $\mathrm{Cv}$ & $10 \mathrm{YR} 4 / 3$ & 70.1 & 17.4 & 12.5 & 6.7 & 7.6 & 0.30 & 0.002 & 0.002 & 0.001 & 0.002 & 0.004 & 0.002 \\
\hline $88-126$ & $\mathrm{Bc}$ & $10 \mathrm{YR} 5 / 4$ & 64.9 & 20.5 & 14.6 & 6.8 & 7.8 & 1.00 & 0.002 & 0.002 & 0.003 & 0.003 & 0.03 & 0.002 \\
\hline $126-160$ & $\mathrm{Bl}$ & $2.5 \mathrm{Y} 3 / 2$ & 61.4 & 14.5 & 24.1 & 6.5 & 6.8 & 2.50 & 0.002 & 0.002 & 0.006 & 0.005 & 0.09 & 0.003 \\
\hline
\end{tabular}


A.C. A. L. FALL / Int. J. Biol. Chem. Sci. 11(4): 1903-1919, 2017
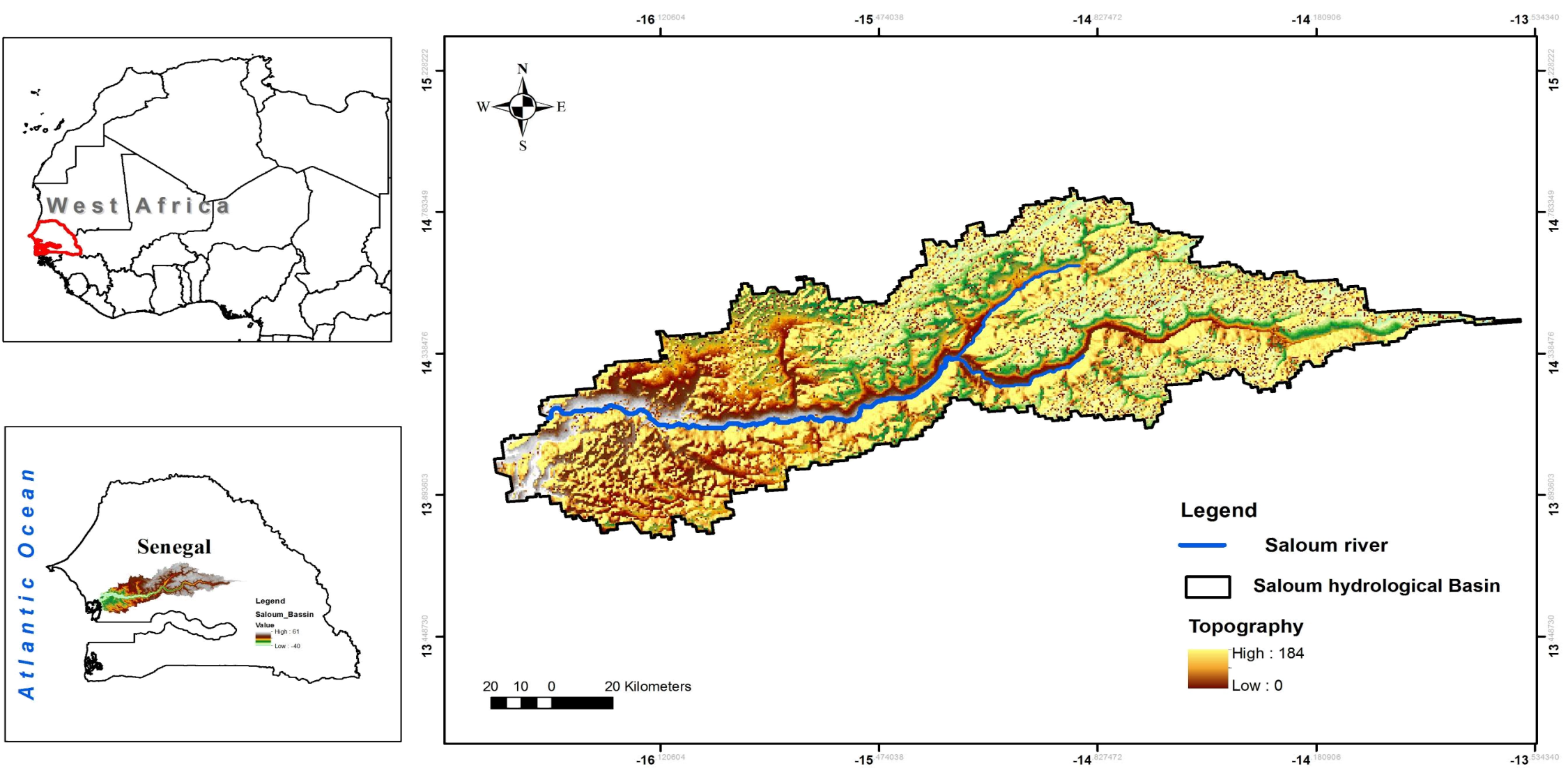

Figure 1: Location Map on the Saloum river basin, West Central Senegal, West Africa. 

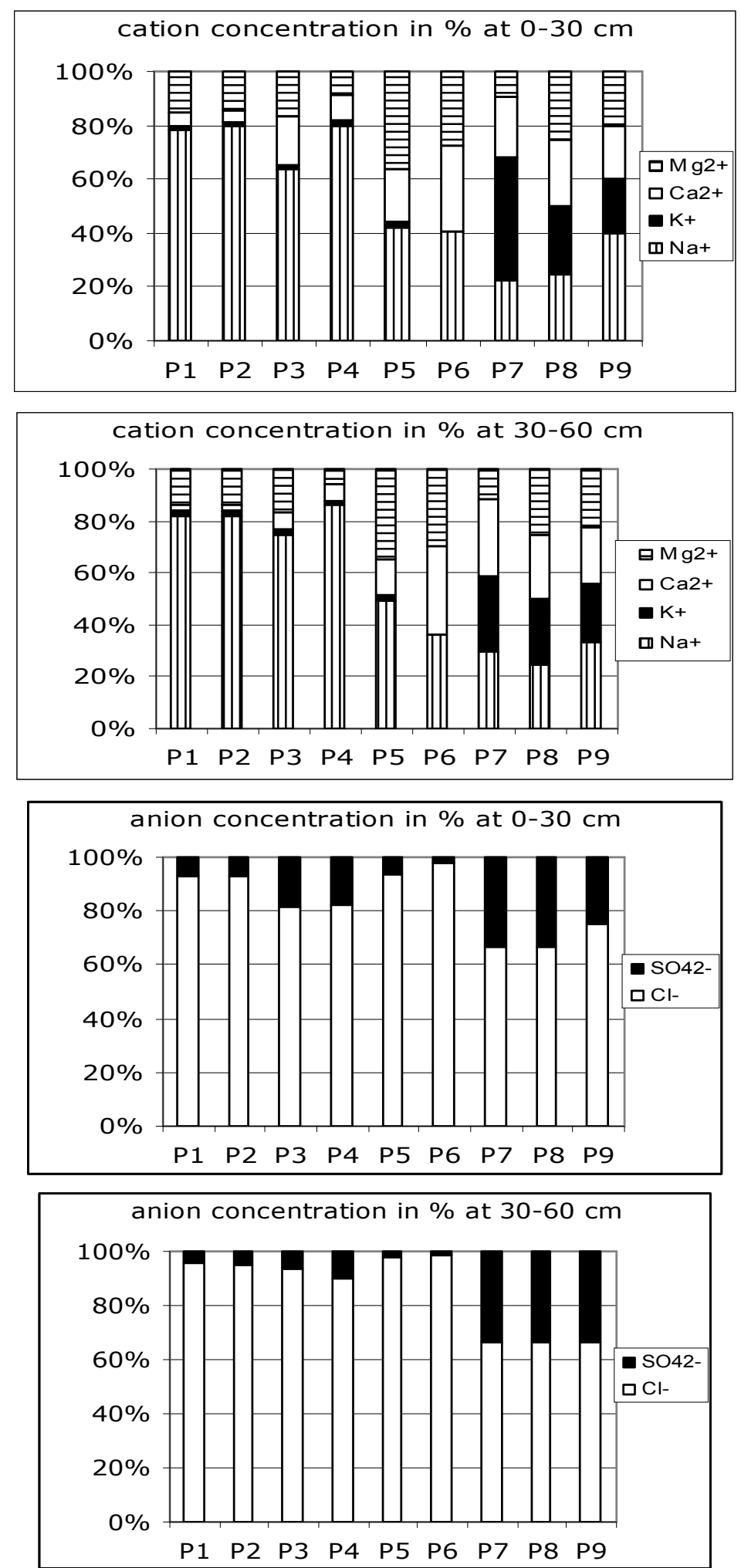

Figure 2: Mean values of water-soluble cations $\left(\mathrm{Na}^{+}, \mathrm{Ca}^{2+}, \mathrm{Mg}^{2+}\right.$, and $\left.\mathrm{K}^{+}\right)$and anions $\left(\mathrm{Cl}^{-}, \mathrm{SO}_{4}^{2-}\right)$ at $30 \mathrm{~cm}$ and $60 \mathrm{~cm}$ depth. 

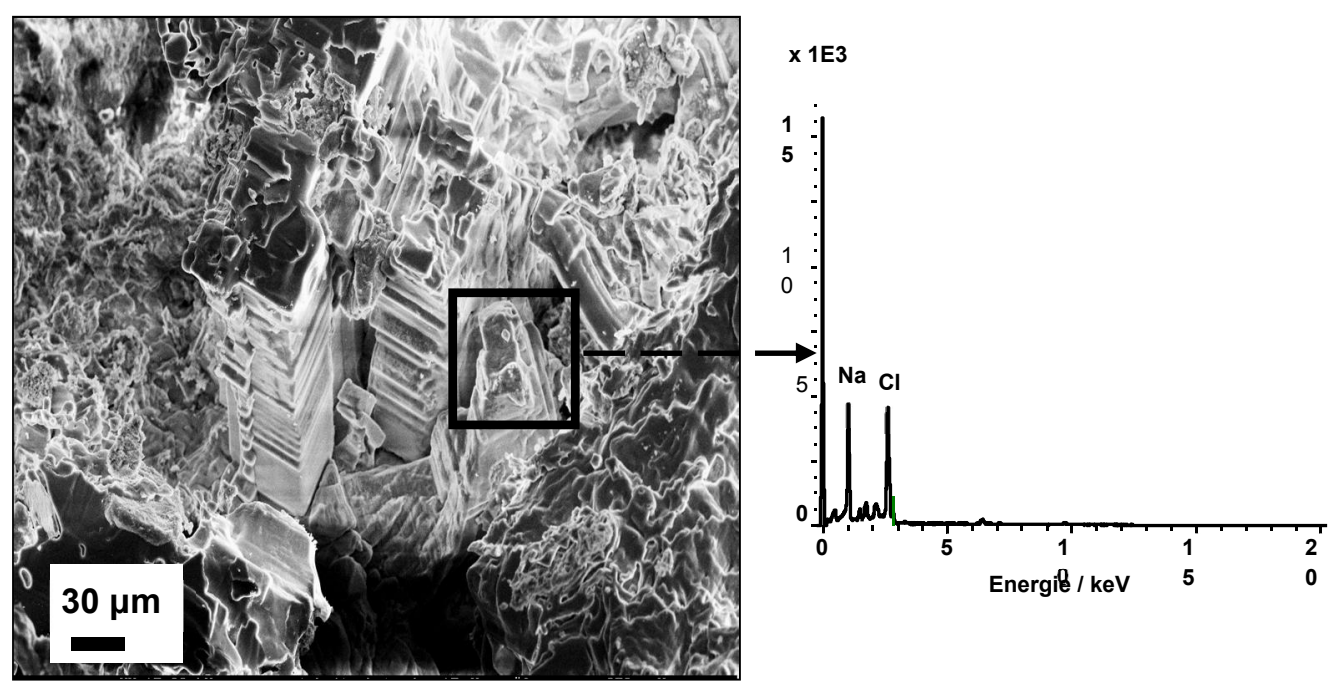

Plate 1a: Floodplain
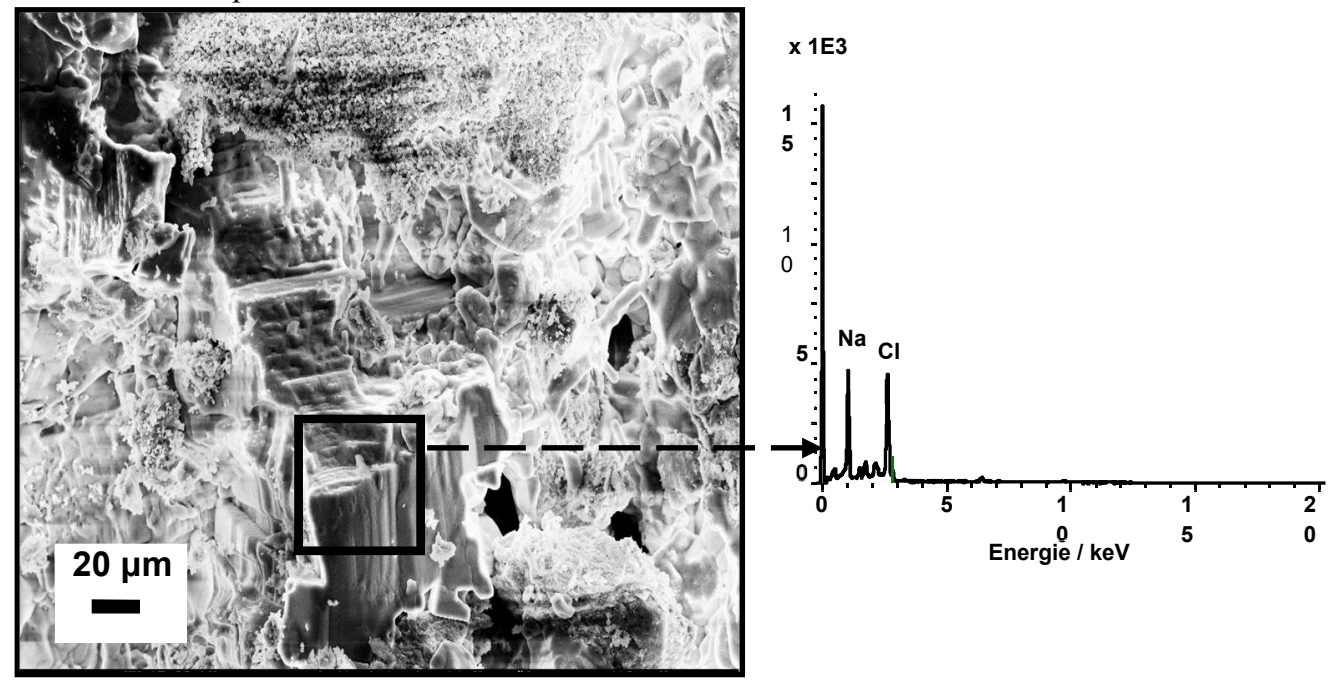

Plate 1b: Low terrace

Plate 1: SEM and EDX showing Halite crystals in the floodplain (P2: Gleyic Hypersalic Solonchak (Sulphatic); Azm/Az horizons: 0-8 cm) and low terrace (P5: Haplic Gleysol (Thionic); Ahz1/Ahz2 horizons: $0-11 \mathrm{~cm}$ ).

\section{DISCUSSION}

Salinization process in the Saloum river Basin

Despite considerable research on coastal saline soils worldwide, the adverse effect of salinity still prevails and poses greater challenges to manage them. Our study demonstrates the close correlation between landscape position and soil salinity illustrated by a two-dimensional salt distribution pattern: horizontal and vertical. Both salt distribution patterns act concurrently with variable intensity according to the landscape position and the season. This variation, common process in coastal plains, reflects a significant dynamic of salts in saline areas (Bresler et al., 1984; Boivin, 1984; Daffé and Sadio, 1988; Sadio, 1991; Hussein and Rabenhorst, 2001). 
The horizontal pattern is appreciable at landscape scale and supports differences in soil salinity between the three topographic positions: floodplain, low terrace and middle terrace. It is determined by the characteristics of the site and the impact of tidal flooding. Because frequency and intensity of tidal flooding increases with decreasing altitude, the floodplain soils contain more soluble salts than low terrace and middle terrace soils. The vertical pattern occurs within soil profiles and is closely linked to soil texture and groundwater dynamic. Depending on the soil texture, the relative water and salt content, and osmotic pressure of the saturation extract can be very different (US Salinity Laboratory, 1969). Soil texture remains therefore an important physical parameter contributing to accentuate vertical salinization processes. It may explain the high salinity of floodplain soils. The fine and nearly homogeneous texture of these soils supports less permeability and thereby promotes continuous upward fluxes of the saline groundwater. As shown by Vieillefon (1977) and Marius (1982), tidal and recently-reclaimed sulphidic soils have large concentrations of soluble salts as a result of prolonged flooding by seawater. We attributed the vertical salt distribution pattern within the low terrace profiles to the presence of texture-contrast soils (TCS), with sandy loam upper layers and silty clay sublayers, which determine the annual depth of the water table and the extent of the evaporation front. Rose et al. (2005) demonstrated in laboratory experiments the high concentration of salt in the particular zone between the soil surface and the water table in sandy loam texture, and explained it by the presence of a discontinuity in saline soil profiles of arid and semi-arid regions. It happens when the evaporative demand is greater than the ability of the soil to conduct water in the liquid phase. The lowest salt concentration was detected in the middle terrace soils. These soils present a sandy texture throughout all profiles. They are under continental influence and seldom face the marine intrusions. It is known that where the sites are at higher elevation and only rarely inundated by seawater, the rate of salinization is expected to be low, as a result of nearly complete leaching of salts during the rainy season.

The impact of seawater in soil properties is well demonstrated in the above analysis. Soils in our toposequence are conspicuously marked by marine actions whether through tidal flooding (horizontal pattern) or water table fluctuations (vertical pattern). They bring water and soluble salts considered as soil genesis factors in this coastal environment. As a result, high salinity of marine water seems to have an important impact on soil genesis in the Saloum river Basin. As related by many authors, the presence of soluble salts in the sediments influences considerably soil formation and development. Maymard and Combeau (1960), Michel (1973), Faure et al. (1980) and Deckers et al. (1997) stated that the last transgression, which started about 2000 years ago, was responsible for incorporation of marine salt into the sediments in which the soils of the coastal area of Senegal have formed. Consequently, the sequence of transgression-regression cycles is thought to have had a great influence on soil formation in the Senegal valley (Barbiero et al., 2005). The influence of marine intrusions appears, therefore, decisive on soil formation in this area. Sadio (1991) suggested, for this reason, that despite their seasonal and spatial variation, salts more soluble than gypsum have to be regarded as an important factor of soil genesis in arid tropics coastal areas, and therefore have to be considered as soil classification criteria.

\section{Mulching as the most efficient method to reclaim saline soils in the Saloum river basin}

Although salinity has adversely affected agriculture for thousands of years, the recognition that salt-affected land can be used for agriculture is relatively recent. Interest in the use of saline land resources has escalated 
over the last 20 years (Ghassemi et al., 1995; Bennett et al., 2009). Many approaches have been attempted to counteract the soil salinization process in the Saloum river Basin. The construction of small dams (mechanical approach) in order to stop saline water from the riverbed was experimented in the 19601970s. The biological approach consisting in the use of salt-tolerant plants (Tamarix sp., Eucalyptus sp., Melaleuca sp., Prosopis sp....) to reclaim saline soils was tested before. This approach is being attempted in a few places of the basin. The limited success of both methods separately applied leads to a new biomechanical approach based on the use of salttolerant plants (Tamarix Aphylla, Atriplex lentiformis; Distichlis spicata), combined with soil ridges surrounding the field to prevent rainwater from running off. The rational behind this combined approach is that it might be possible, through the massive planting of Tamarix trees, to lower the saline water table in the salt affected area. As a result, rainwater could replace the evacuated soil volume and in the process leach the salts from the upper soil layers. This method could be successful in the context of saline soils coupled with a long rainy season facilitating a well leaching process. But it can be harmful in the Saloum river Basin characterized by low annual rainfall and severe acid conditions.

Soil management strategies in this part of Senegal, and coastal West African areas at large, have thus to take into account the complex interactions between salinity and acidity. Because lowering the water table creates aerobic conditions on the topsoil, which leads to the oxidation of pyrite present in soil sediments. The oxidation of pyrite gives rise to severe acidity, which renders these soils of little value for agriculture. Also if promoting a high water table, as suggested by some authors, seems a practical way to avoid pyrite oxidation and soil acidification, it should be realised that maintaining a high water table is not advisable in many areas of the Saloum river Basin; the presence of saline groundwater at shallow depths (rooting zone) could be detrimental for plant growth.
The present study shows a vertical gradient of salt movement consisting in alternating bottom-up (capillary rise of groundwater towards the soil surface) and topdown (infiltration of soluble salts from the seawater). So, any technique that would stop or hinder the capillary rise of groundwater and salt concentration on the top layers of soil profiles is required. The use of surface-applied or incorporated straw mulches to reduce the strong evaporative demand of the atmosphere could be a practical way. Mulching is the most cost effective means of soil protection in the plant production, because of a range of positive effects on the soil fertility and other factors important for plant production (Shelton et al., 1995). Moreover, mulch improves soil conditions, especially reduces water evaporation from soil and helps maintaining stable soil temperature ( $\mathrm{Ji}$ and Unger, 2001; Kar and Kumar, 2007). The cover of mulch influences soil moisture as well (Ramakrishna et al., 2006). Mulch maintains stable soil moisture, especially in surface soil layer (Dvořák et al., 2011). As a consequence of reduced evaporation, soil mulching benefits the conservation of water, particularly in the topsoil, decreases the evapo-concentration of the salts present in the irrigation water and the soil solution (Zhang et al., 2008), and minimizes soil salinization and sodication (Chaudhry et al., 2004; Rahman et al., 2006; Aragüés et al., 2014). Likewise, Singh et al. (2016) investigated long-term effects of tillage on crop yield and physicochemical properties of sodic soils and conclude that continuous tillage and cropping can be useful for physical and chemical restoration of sodic soils. Mulch could maintain the water table at rational depth and promote higher moisture in the topsoil by reducing the vapour flow out of the soil profile. The net result is a relatively greater downward movement of water and salt in mulched soil than in bare soil (Carter and Fanning, 1964). As a consequence, mulching of soil surface reduces evaporation losses and salt build-up in the topsoil. Also, lowering the aeration rate in the topsoil avoids the 
oxidation of pyrite and subsequent soil acidification. Grigg et al. (2006) observed in laboratory study, that mulch application improved infiltration, increased soil moisture retention and reduced surface crust strength. In the field, mulches incorporated to a depth of $0.15 \mathrm{~m}$ at application rate at least $20 \mathrm{tha}^{-1}$ straw or $80 \mathrm{t} \mathrm{ha}^{-1}$ sawdust were needed to mitigate capillary rise of salts during drying cycles and support satisfactory vegetation cover. Rosicky et al. (2006) used different methods: ridging, mulching and liming; to reclaim acid sulphate soil scalds of some costal floodplains of New South Wales, Australia. They found that mulching was the most important single treatment; it minimised significantly the build-up of surface salinity in dry times.

Mulching appears, therefore, very efficient in reclaiming saline soils present in the Saloum river basin. It requires, however, scientific investigation of soil properties before any application. Beye (1973) applied the mulching method to reclaim saline acid soil in the coastal area of southwestern Senegal and obtained up to $50 \%$ reduction of salinity in the topsoil (around $30 \mathrm{~cm}$ ) after four years despite low rainfall during the trial period. But the lack of soil characterization makes these results really transient, limiting their large-scale application. Accordingly, Grigg et al. (2006) suggested further research in order to ascertain the long-time efficiency of the mulching technique.

\section{Conclusion}

Previous research in the coastal area of the Saloum river Basin attributed the soil salinization processes to the severe drought of the 70s involving a fall of water table and the topographic setting which determines the impact of seawater intrusions. Nevertheless, they fail to investigate the salt distribution pattern at landscape scale and within soil profiles. Our results demonstrated the twodimensional salt distribution pattern and the influence of water table and soil texture in the dynamic of soil salinity. Soil management strategies in this part of Senegal have also to take into account the interactions between salinity and acidity. Because lowering the water table creates aerobic conditions on the topsoil, which leads to the oxidation of pyrite present in the sediments of this coastal area. Also, maintaining a high water table in order to control pyrite oxidation is not advisable in many areas of the Saloum river Basin. The presence of saline groundwater at shallow depth could be harmful to plant growth. The mulching technique appears as the most sustainable soil management strategy in this coastal environment. It may reduce soil salinization by lessening the strong evaporation demand and subsequent formation of surface salt crust. It may also limit soil acidification in promoting relative soil moisture in the upper horizons of soil profiles.

\section{REFERENCES}

Acosta JA Jansen B, Kalbitz K, Faz A, Martínez-Martínez S. 2011. Salinity increases mobility of heavy metals in soils. Chemosphere, 85: 1318-1324.

Amezketa E. 2006. An integrated methodology for assessing soil salinization, a precondition for land desertification. Journal of Arid Environment, 67: 594-606.

Aragüés R, Medina ET, Clavería I. 2014. Effectiveness of inorganic and organic mulching for soil salinity and sodicity control in a grapevine orchard dripirrigated with moderately saline waters. Sp. J. Ag. Res., 12 (2): 501-508.

Arndt JL, Richardson JL. 1993. Temporal variations in the salinity of shallow groundwater from the periphery of some North Dakota wetlands (USA). $J$. Hydro., 141: 75-105.

Åström M, Björklund A. 1997.Geochemistry and acidity of sulphide-bearing postglacial sediments of western Finland. Environmental Geochemistry and Health, 19(4): 155-164.

Barbiero L, de Queiroz Neto JP, Ciornei G, Sakamoto AY, Capellari B, Fernandes E, Valles V. 2002. Geochemistry of water and ground water in the Nhecolândia, Pantanal of Mato Grosso, Brazil: variability and associated processes. 
Wetlands, 22: 528-540.

Barbiero L, Mohamedou AO, Roger L, Furian S, Aventurier A, Remy JC, Marlet S. 2005. The origin of Vertisols and their relationship to acid sulfate soils in the Senegal valley. Catena, 59: 93-116

Bauder TA, Davis JG, Waskom RM. 2014. Managing Saline Soils. Fact Sheet No. 0.503, Crop Series | Soil; Colorado State University, $5 \mathrm{p}$.

Bennett SJ, Barrett-Lennard EG, Colmer TD. 2009. Salinity and waterlogging as constraints to saltland pasture production: A review. Agriculture, Ecosystems and Environment, 129: 349360.

Bèye G. 1973. Une méthode simple de dessalement des sols de tanne de Casamance: le paillage. Agro Trop., 28(5): 537-549.

Boivin P. 1984. Etude pédologique de la vallée de Koubalan (Kalounayes). Etude de la variabilité spatiale du $\mathrm{pH}$ et de la conductivité d'un sol de tanne. ORSTOM/Dakar, $70 p+4$ cartes.

Boman A, Åström M, Fröjdö S. 2008. Sulfur dynamics in boreal acid sulfate soils rich in metastable iron sulfide - The role of artificial drainage. Chem. Geol., 255: 68-77.

Bresler E, Dagan G, Wagenet RJ, Laufer A. 1984. Statistical analysis of salinity and texture effects on spatial variability of soil hydraulic conductivity. Soil. Sci. Soc. Am. J., 48: 16-25.

Bui EN. 2013. Soil salinity: A neglected factor in plant ecology and biogeography. Journal of Arid Environments, 92: 14-25.

Carter DL, Fanning CD.1964. Combining surface mulches and periodic water applications for reclaiming saline soils. Soil. Sci. Soc. Am. Proc., 28: 564-567.

Chaudhry MR, Aziz AM, Sidhu M. 2004. Mulching impact on moisture conservation, soil properties and plant growth. Pakistan Journal of Water Resources, 82: 1-8.
Costelloe JF, Payne E, Woodrow IE, Irvine EC, Western AW, Leaney FW.2008. Water sources accessed by arid zone riparian trees in highly saline environments, Australia. Oecologia, 156: $43-52$.

Daffé M, Sadio S. 1988. Etude pédologique. Régénération des sols salins du Bassin du Sine Saloum. Projet UNSO/SEN/83/X02-ISRA/DRPF, 78p + 90p Annexes.

Dowling T, Summerell GK, Walker J. 2003. Soil wetness as an indicator of stream salinity: a landscape position index approach. Environmental Modelling \& Software, 18: 587-593.

Dvořák P, Tomášek J, Hamouz K, Kuchová P. 2011. Effect of mulching materials on the soil temperature, soil water potential, number and weight tubers of organic potatoes. Poster section / $3^{\text {rd }}$ Scientific Conference /Prague.

Fall ACAL. 2010. Soil Formation and Mineral Distribution in a Saline Acid Sulfate Landscape of West Central Senegal, West Africa. PhD Thesis, Hohenheimer Bodenkundliche Hefte, Heft 98. 179 p.

Fall ACAL, Montoroi JP, Stahr K. 2014. Coastal acid sulfate soils in the Saloum River basin, Senegal. CSIRO PUBLISHING, Soil Research, 52: 671684.

Faye E, Camara M, Touré MA, Mbaye A. 2014. Evaluation et amélioration du comportement de Atriplex lentiformis (Torr.) S. Watson en milieux salés au Sénégal. Int. J. Biol. Chem. Sci., 8(4): 1697-1709.

Fanning DS, Burch SN. 1997. Acid sulphate soils and some associated environmental problems. In Soils and Environment, Auerswald K et al. (eds). Catena Verlag GMBH, Reiskirchen ; 145-158.

FAO. 2008. FAO Land and Plant Nutrition Management Service; Available at http://www.fao.org/ag/agl/agll/spush 
Ghassemi F, Jakeman AJ, Nix HA. 1995. Salinisation of Land and Water Resources: Human Causes, Extent, Management and Case Studies. UNSW Press: Sydney.

Grigg AH, Sheridan GJ, Pearce AB, Mulligan DR. 2006. The effect of organic mulch amendments on the physical and chemical properties and revegetation success of a saline-sodic minespoil from central Queensland, Australia. Australian Journal of Soil Research, 44: 97-105.

Hasegawa PM, Bressan RA, Zhu JK, Bohnert HJ. 2000. Plant cellular and molecular responses to high salinity. Annual Review of Plant Physiology and Plant Molecular Biology, 51: 463-499.

Holland KL, Tyerman SD, Mensforth LJ, Walker GR. 2006. Tree water sources over shallow, saline groundwater in the lower River Murray, south-eastern Australia: implications for groundwater recharge mechanisms. Australian Journal of Botany, 54: 193-205.

Humphries MS, Kindness A, Ellery WN, Hughes JC, Bond JK, Barnes KB. 2011. Vegetation influences on groundwater salinity and chemical heterogeneity in a freshwater, recharge floodplain wetland, South Africa. J. Hydro., 411: 130-139

Hussein AH, Rabenhorst MC. 2001. Tidal inundation of transgressive coastal areas: Pedogenesis of Salinization and Alkalinization. Soil Sci. Soc. Am. J., 65: 536-544.

Ji S, Unger PW. 2001. Soil water accumulation under different precipitation, potential evaporation and straw mulch conditions. Soil Sci. Soc. Am. J., 65: 442-448.

Jolly ID, Walker GR, Thorburn PJ. 1993. Salt accumulation in semi-arid floodplain soils with implications for forest health. J. Hydro., 150: 589-614.

Kar G, Kumar A. 2007. Effects of irrigation and straw mulch on water use and tuber yield of potato in eastern India.
Agriculture Water Management, 94: 109-116.

Lamontagne S, Leaney FW, Herczeg AL. 2005. Groundwater-surface water interactions in a large semi-arid floodplain: implications for salinity management. Hydrological Processes, 19: $3063-3080$.

Lavkulich LM. 1981. Methods Manual. Pedology Laboratory, Department of Soil Science. University of British Columbia, Vancouver, Canada.

Maathuis FJM. 2006. The role of monovalent cation transporters in plant responses to salinity. Journal of Experimental Botany, 57: 1137-1147.

Marius C. 1985. Les Mangroves du Sénégal et de la Gambie. Ed. ORSTOM, Travaux et Documents 193 : Paris.

McCarthy TS, Ellery WN, Ellery $\mathrm{K}$. 1993.Vegetation-induced, subsurface precipitation of carbonate as an aggradational process in the permanent swamps of the Okavango (delta) fan, Botswana. Chemical Geology, 107: 111131.

Michel P. 1973. Les bassins des fleuves Sénégal et Gambie. Etude géomorphologique. Mémoire ORSTOM 63. Paris, France.

Mills AJ. 2006. The role of salinity and sodicity in the dieback of Acacia xanthophloea in Ngorongoro Caldera, Tanzania. African Journal of Ecology, 44: 61-71.

Rahman MJ, Uddin MS, Bagum SA, Mondol AT, Zaman MM. 2006. Effect of mulches on the growth and yield of tomato in the coastal area of Bangladesh under rainfed condition. International Journal of Sustainable Crop Production, 1: 6-10.

Ohrtman MK, Sher AA, Lair KD. 2012. Quantifying soil salinity in areas invaded by Tamarix spp. Journal of Arid Environments, 85: 114-121.

Ramakrishna A, Tam HM, Wani SP, Long TD. 2006. Effect of mulch on soil temperature, moisture, weed infestation 
and yield of groundnut in northern Vietnam. Field Crops Research, 95: 115-125.

Rengasamy P. 2006.World salinization with emphasis on Australia Journal of Experimental Botany, 57: 1017-1023.

Rengasamy P. 2010. Soil processes affecting crop production in salt-affected soils. Functional Plant Biology, 37: 613-620.

Rose DA, Konukcu F, Gowing JW. 2005. Effect of water table depth on evaporation and salt accumulation from groundwater. Australian Journal of Soil Research, 43: 565-573.

Rosicky MA, Slavich P, Sullivan LA, Hughes M. 2006. Techniques for revegetation of acid sulfate soil scalds in the coastal floodplains of New South Wales, Australia: ridging, mulching and liming in the absence of stock grazing. Australian Journal of Experimental agriculture, 46: 1589-1600.

Sadio S. 1991. Pédogénèse et Potentialités Forestières des Sols Sulfatés Acides Salés des Tannes du Sine Saloum, Sénégal. Orstom: Paris.

Salama RB, Farrington P, Bartle GA, Watson GD. 1993. The chemical evolution of groundwater in a first-order catchment and the process of salt accumulation in the soil profile. J. Hydro., 143: 233-258.

Schlichting E, Blume HP, Stahr K. 1995. Bodenkundliches Praktikum. Blackwell Wissenschafts-Verlag: Berlin.

Schofield RV, Kirkby MJ. 2003. Application of salinization indicators and initial development of global soil salinization scenario under climatic change. Global Biogeochemical Cycles, 17: 1078.

Sène JHB, Matty F, Diatta M. 2014. Caractérisation des sols de la vallée rizicole de Tamra dans l'île de Mar, Centre-Ouest du Sénégal. Int. J. Biol. Chem. Sci., 8(2): 794-810.

Shelton DP, Dickey SD, Hachman SD, Steven S, Fairbanks KD. 1995. Corn residue cover on soil surface after planting for various tillage and planting system. Journal of Soil and Water Conservation, 50: 399-404.

Singh K, Mishra AK, Singh B, Singh RP, Patra DD. 2016. Tillage effects on crop yield and physicochemical properties of sodic soils. Land Degradation \& Development, 27(2): 223-230.

Stone Y, Ahern CR, Blunden B. 1998.Acid Sulfate Soils Manual 1998. ASSMAC, Wollongbar, NSW Agriculture, unpublished.

Thiam A, Samba SAN, Noba K, Ndiaye JP, Diatta M, Wade M. 2015. Etude de la variation de la végétation en milieux salé et acide au Sénégal. Int. J. Biol. Chem. Sci., 9(1): 155-175.

United Nations Environment Program. 1991. Status of desertification and implementation of the United Nations Plans of action to combat desertification. UNEP, Nairobi.

United States Salinity Laboratory Staff. 1969. Diagnosis and Improvement of Saline and Alkali Soils. Agriculture Handbook No. 60, Rev. ed. United States Department of Agriculture, Washington, DC.

Wongpokhom N, Kheoruenromne I, Suddhiprakarn A, Gilkes RJ. 2008. Micromorphological properties of salt affected soils in Northeast Thailand. Geoderma, 144: 158-170.

Zhang QT, Inoue M, Inosako K, Irshad M, Kondo K, Qui GY, Wang SH. 2008. Ameliorative effect of mulching on water use efficiency of swisschard salt accumulation under saline irrigation. Journal of Food, Agriculture and Environment, 3-4: 480-485.

Zheng Z, Zhang F, Ma F, Chai X, Zhu Z, Shi J, Zhang S. 2009. Spatiotemporal changes in soil salinity in a drip-irrigated field. Geoderma, 149: 243-248. 